Article

\title{
Targeted Isolation of Rubrolides from the New Zealand Marine Tunicate Synoicum kuranui
}

\author{
Joe Bracegirdle ${ }^{1,2,3} \oplus$, Luke J. Stevenson ${ }^{2,3,4}$ (), Michael J. Page ${ }^{5}$, Jeremy G. Owen ${ }^{2,3,4}$ and \\ Robert A. Keyzers $1,2,3, *$ (D) \\ 1 School of Chemical and Physical Sciences, Victoria University of Wellington, Wellington 6012, New Zealand; \\ joe.bracegirdle@vuw.ac.nz \\ 2 Centre for Biodiscovery, Victoria University of Wellington, Wellington 6012, New Zealand; \\ luke.stevenson@vuw.ac.nz (L.J.S.); jeremy.owen@vuw.ac.nz (J.G.O.) \\ 3 Maurice Wilkins Centre for Molecular Biodiscovery, Auckland 1142, New Zealand \\ 4 School of Biological Sciences, Victoria University of Wellington, Wellington 6012, New Zealand \\ 5 National Institute of Water \& Atmospheric Research (NIWA), P.O. Box 893, Nelson 7010, New Zealand; \\ mike.page@niwa.co.nz \\ * Correspondence: robert.keyzers@vuw.ac.nz; Tel.: +64-4-4635117
}

Received: 3 June 2020; Accepted: 23 June 2020; Published: 27 June 2020

\begin{abstract}
Global natural products social (GNPS) molecular networking is a useful tool to categorize chemical space within samples and streamline the discovery of new natural products. Here, we demonstrate its use in chemically profiling the extract of the marine tunicate Synoicum kuranui, comprised of many previously reported rubrolides, for new chemical entities. Within the rubrolide cluster, two masses that did not correspond to previously reported congeners were detected, and, following MS-guided fractionation, led to the isolation of new methylated rubrolides $\mathrm{T}$ (3) and (Z/E)-U (4). Both compounds showed strong growth inhibitory activity against the Gram-positive bacteria Bacillus subtilis, with minimum inhibitory concentration (MIC) values of 0.41 and $0.91 \mu \mathrm{M}$, respectively.
\end{abstract}

Keywords: rubrolide; GNPS; Synoicum kuranui; antibacterial

\section{Introduction}

Molecular networking (MN) through the global natural products social molecular networking (GNPS) platform [1] is a cutting-edge contemporary tool for the screening of marine natural product extracts [2]. In recent years, the tool has been used to direct the isolation of many single metabolites (particularly peptides, such as pagoamide) [3]; however, it has also proven extremely powerful in the discovery of new congeners within molecular classes or families [4,5]. MN links compounds (nodes) based on spectral alignment of their $\mathrm{MS}^{2}$ spectra, therefore, many metabolites within a structural class in an extract generate large constellations comprising many interconnected nodes. These clusters stand out from the noise in a large network, prioritizing samples for more detailed investigation (Figure S1). MN has also proved extremely useful for the detection of previously unreported metabolites in extensively well studied families of compounds, or from heavily investigated taxa [6-9].

As part of our continuing investigation of the secondary metabolites produced by marine invertebrates collected from the South Pacific [10-13], we recently reported the first study utilizing MN to examine the chemical constituents of various Tongan marine tunicates [14]. The major constellation of the network consisted of three linked clusters of nodes, and prioritization of the fractions containing lamellarin sulfates resulted in the characterization of the first new sulfated lamellarins reported in over 20 years [14]. Tunicates have been an excellent source of natural products to date, including 
the FDA-approved plitidepsin (Aplidin ${ }^{\circledR}$ ) and trabectedin $\left(\right.$ Yondelis $\left.{ }^{\circledR}\right)$; however, the number of new tunicate-derived compounds reported annually is decreasing, with $45 \%$ less reported in 2017 compared to 2016 [15].

Here, we explored the chemical space occupied by metabolites of an extract of the New Zealand tunicate Synoicum kuranui. The genus Synoicum is one of nine currently accepted genera of the tunicate family Polyclinidae, comprising 82 different species [16], including the source of the potent cytotoxic palmerolides, first isolated by Baker and co-workers from an Antarctic S. adarenum sample [17], as well as numerous alkaloids [18-20]. Synoicum also commonly harbors non-nitrogenous polyaromatic butenolides, led by the rubrolides, which are often co-isolated with other butenolide-containing families, such as prunolides and cadiolides. Like many alkaloids, these are formed by the condensation of multiple aromatic amino acid-derived metabolites [21], but do not themselves contain nitrogen. The rubrolides were first isolated from a Canadian (Queen Charlotte Islands, British Columbia) tunicate Ritterella rubra [22], with the full natural panel now $>20$ compounds after subsequent isolations from tunicates S. globosum [23], S. blochmanni [24], two unidentified Synoicum species [25,26], Pseudodistoma antinboja [27] and the marine-derived fungus Aspergillus terreus [28]. Given the significant number of known compounds within the class, finding new congeners is a potentially difficult exercise, however, $\mathrm{MN}$ can provide assistance for this even within well studied organisms.

\section{Results and Discussion}

The bright orange/red tunicate S. kuranui (Figure S2; Millar, 1982) [29], was collected from Great Barrier Island in the Hauraki Gulf, NZ, at depth of $21 \mathrm{~m}$ with SCUBA as part of the National Institute of a Water \& Atmospheric Research (NIWA) collection. This tunicate is native to NZ waters, first recorded from Great Barrier Island, and has also been observed around the North Cape and Fiordland [30]. With no previously reported investigations of the species, this organism was included in a mass spectrometric screen of South Pacific tunicates, visualized using GNPS and Cytoscape (Figure S1). Constellations consisting of nodes made up from only one organism are a clear lead for similarly structured secondary metabolites. In the network, the second largest constellation consisted of nodes solely from the S. kuranui extract (in pink, constellation A), and thereby highlighted the tunicate for further investigation.

The methanolic extract was fractionated with HP-20 ${ }^{\circledR}$ (poly(styrene-divinylbenzene) copolymer (PSDVB)) resin using mixtures of $\mathrm{H}_{2} \mathrm{O}$ and acetone, and was analyzed by ${ }^{1} \mathrm{H}$ NMR spectroscopy and mass spectrometry. The ${ }^{1} \mathrm{H}$ NMR spectrum revealed numerous peaks of interest in the aromatic region, and a notable absence of peaks typically associated with fats and primary metabolites in the $0-2 \mathrm{ppm}$ range (Figure S3). The sample was then further purified using reversed-phase HPLC to afford the known rubrolides $\mathrm{A}$ and $\mathrm{B}$ ( $\mathbf{1}$ and $\mathbf{2})$ and new rubrolides $\mathrm{T}$ and $\mathrm{U}$ ( $\mathbf{3}$ and $\mathbf{4})$ (Figure 1$)$.

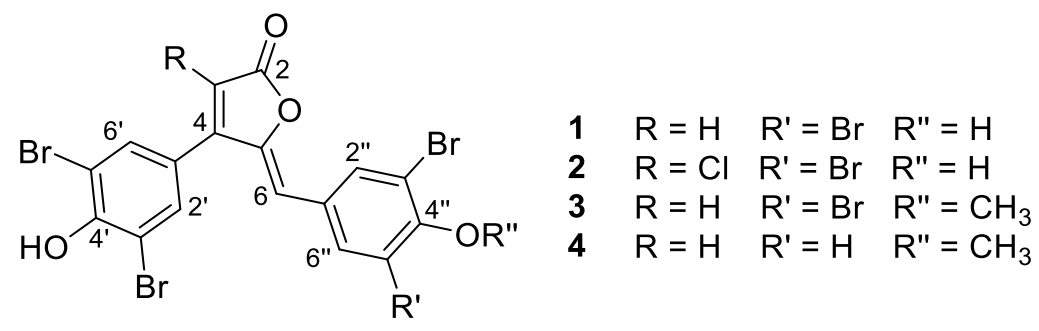

Figure 1. Compounds isolated from S. kuranui.

The major compound, rubrolide A (1), was isolated as a yellow film, and HRESIMS analysis gave a deprotonated molecular ion cluster at $m / z 590.7075$ indicative of the molecular formula $\mathrm{C}_{17} \mathrm{H}_{7} \mathrm{O}_{4} \mathrm{Br}_{4}$ (calcd. 590.7083). The ${ }^{13} \mathrm{C}$ NMR spectrum consisted of 13 deshielded resonances, while the ${ }^{1} \mathrm{H}$ NMR spectrum showed four deshielded singlet methine signals, with two integrating for two $\left(\delta_{\mathrm{H}} 7.77\right.$ and 8.05$)$ and one $\left(\delta_{\mathrm{H}} 6.35\right.$ and 6.55) relative protons each. This data was used to search the MarinLit database [31], 
with rubrolide A (1) being the clear hit both spectroscopically and from a taxonomic perspective. A comparison of the NMR data from the original isolation confirmed this [22]. A minor compound, also isolated as a yellow film, was subject to HRESIMS analysis, which detected a deprotonated molecular ion cluster at $m / z 624.6694$ indicative of the molecular formula $\mathrm{C}_{17} \mathrm{H}_{7} \mathrm{O}_{4} \mathrm{Br}_{4} \mathrm{Cl}$ (calcd. 624.6694). This was dereplicated as rubrolide B (2), after the matching of MS and ${ }^{1} \mathrm{H}$ NMR data [22].

With annotation of the structural class of the major metabolites deduced from the $75 \%$ acetone HP-20 ${ }^{\circledR}$ fraction, molecular networking was then used to probe the remaining two S. kuranui fractions for new unreported congeners, along with dereplication of other known minor metabolites. From the major constellation generated by the analysis of the remaining $30 \%$ and $100 \%$ acetone fractions, compounds 1 and $\mathbf{2}$, and 10 other nodes were putatively annotated, based on the precursor ion matching the $\mathrm{m} / \mathrm{z}$ of a previously reported rubrolide (Figure 2). Based on the connections between nodes and precursor ions, two previously unreported rubrolide masses were detected, with the molecular formulae $\mathrm{C}_{18} \mathrm{H}_{10} \mathrm{O}_{4} \mathrm{Br}_{4}$ and $\mathrm{C}_{18} \mathrm{H}_{11} \mathrm{O}_{4} \mathrm{Br}_{3}$. These ions were then used to prioritize the HPLC fractions for further purification.

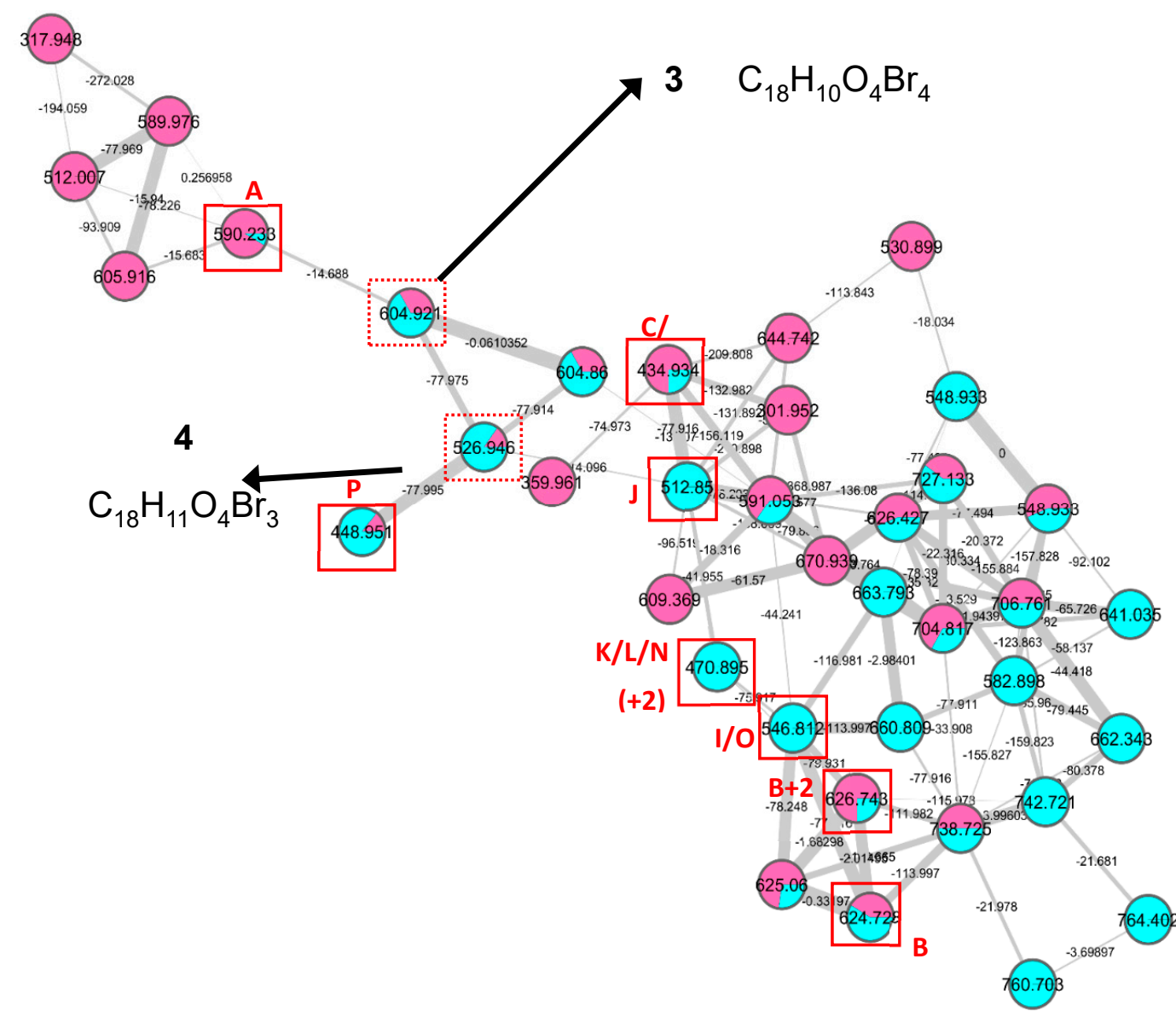

Figure 2. Global natural products social (GNPS) molecular networking (MN) of S. kuranui HP-20 ${ }^{\circledR}$ fractions. The nodes are labelled by the monoisotopic precursor ion $\mathrm{m} / \mathrm{z}$ value, and annotated based on their sum precursor ion intensity with pink the $30 \%$ acetone fraction and aqua the $100 \%$ acetone HP-20 ${ }^{\circledR}$ fraction. Red letters denote known rubrolide annotations, while +2 denotes a node detected from its $M+2$ precursor ion. The edges are labelled by the precursor ion differences, and the thickness is dependent on the cosine value of the two nodes.

Through a targeted isolation procedure guided by MS, a new analogue named rubrolide T (3), was isolated as a yellow film. Analysis of the deprotonated molecule at $m / z 604.7254$ in the HRESIMS indicated the molecular formula $\mathrm{C}_{18} \mathrm{H}_{9} \mathrm{O}_{4} \mathrm{Br}_{4}$ (calcd. 604.7240), consisting of 12 double bond equivalents 
(DBE). The presence of four bromine atoms was clear from the 1:4:6:4:1 quintet isotopic distribution pattern (Figure S8). The ${ }^{13} \mathrm{C}$ NMR spectrum consisted of one methoxy and 13 deshielded resonances, including an $\alpha, \beta$-unsaturated ester carbonyl at $\delta_{\mathrm{C}} 168.5$, which, together, indicated an element(s) of symmetry within the molecule. The ${ }^{1} \mathrm{H}$ NMR spectrum showed a methoxy $\left(\delta_{\mathrm{H}} 3.83\right)$ and four aromatic singlets, two integrating for two relative protons each $\left(\delta_{\mathrm{H}} 7.59\right.$ and 8.15), and the other two $\left(\delta_{\mathrm{H}} 6.21\right.$ and 6.44) for one proton, respectively. No COSY correlations were observed, therefore, it was likely no protons were vicinal to another.

The two-proton aromatic methine $\delta_{\mathrm{H}} 8.15$ (H-2"/H-6") showed correlations to $\delta_{\mathrm{C}} 134.2$ in both the HSQC and HMBC spectra, thus, was indicative of two methines symmetrically substituted about a phenyl ring. This proton resonance also showed HMBC correlations to $\delta_{\mathrm{C}} 153.1,117.7$ and 108.2. The correlation to an oxygenated carbon at $\delta_{\mathrm{C}} 153.1\left(\mathrm{C}-4^{\prime \prime}\right)$ was shared with that of methoxy $\delta_{\mathrm{H}} 3.83$, which must be on the same ring. Owing to the presence of the singlet methine and the symmetry required, these three substituents must be meta to one another. As the carbon $\delta_{\mathrm{C}} 108.2(\mathrm{C}-6)$ is protonated (HSQC; $\delta_{\mathrm{H}} 6.44$ ), and does not show a COSY correlation to $\delta_{\mathrm{H}} 8.15$, it must be outside the aromatic ring, thus, a pair of brominated carbons were assigned to positions $C-3^{\prime \prime} / C-5^{\prime \prime}\left(\delta_{C} 117.7\right)$, and substructure I was deduced (Figure 2). An analogous workflow starting from the other two-proton aromatic methine $\left(\delta_{\mathrm{H}} 7.59\right)$ also derived a 1,3,4,5-tetrasubstituted phenyl ring, however, with no methyl substitution at the $C-4$ 'phenol, giving rise to substructure II. The remaining proton singlet $\left(\delta_{\mathrm{H}} 6.21\right)$ was assigned to $\mathrm{C}-3$ of the central butenolide ring, as it had the only correlation to ester carbonyl C-2 $\left(\delta_{\mathrm{C}}\right.$ 168.5). H-3 also shared HMBC correlations to quaternary carbon $\delta_{\mathrm{C}} 156.6$ with both $\mathrm{H}-6$ and $\mathrm{H}-22^{\prime} / 6^{\prime}$, which assigned this as $\mathrm{C}-4$, and, consequently, $\delta_{C} 148.8$ to oxygenated $\mathrm{C}-5$ (Figure 3 ). This molecule differs from the major compound rubrolide A 1 solely by the presence of a methoxy group at $C-4 "$, and as a new member of the class, is termed rubrolide $\mathrm{T}$ (Tables 1 and 2).

It was noted that when two chromatographic fractions, each containing ions at $\mathrm{m} / \mathrm{z} 526.8143$ (HRESIMS), were purified by HPLC, there were two separate UV-detected peaks with identical ion masses observed in each sample. Upon ${ }^{1} \mathrm{H}$ NMR analysis, both isolated HPLC peaks had identical NMR resonances, however, the resonances differed in relative intensities, suggesting the presence of two isomers. This suggested both of the distinct HPLC fractions contained the same two separate compounds. This has been observed before for rubrolides O, P, Q, and also cadiolide F [25,32], all of which all exist as two separable but interchangeable isomers, differing by their $\Delta_{5,6}$ geometry. All previous examples have been mono-brominated on the benzylidene ring, and are often methylated at the phenol.

The major rubrolide $U$ isomer $(Z-4)$ was isolated as a yellow film, and HRESIMS analysis detected the deprotonated molecule at $m / z$ 526.8143, indicative of the molecular formula $\mathrm{C}_{18} \mathrm{H}_{10} \mathrm{O}_{4} \mathrm{Br}_{3}$ (calcd. 526.8135). The presence of three bromine atoms was clear from the 1:3:3:1 quartet isotopic distribution pattern (Figure S17). The ${ }^{13} \mathrm{C}$ NMR spectrum showed a similar pattern of peaks as 3, including the single methoxy resonance, however $Z-4$ has two extra proton signals and with one less bromine in the elemental formula, an element of symmetry was broken (Table 1). In the ${ }^{1} \mathrm{H}$ NMR spectrum, the coupling pattern of the peaks at $\delta_{\mathrm{H}} 7.19(\mathrm{~d}, 8.7 \mathrm{~Hz}), 7.81(\mathrm{dd}, 8.7,2.2 \mathrm{~Hz})$ and 8.11 $(\mathrm{d}, 2.2 \mathrm{~Hz})$ was characteristic of a 1,2,4-trisubstituted aromatic ring, while the singlet at $\delta_{\mathrm{H}} 7.56$, integrating for two relative protons, indicated a 1,3,4,5-tetrasubstituted structure (Table 2).

The methoxy group at $\delta_{\mathrm{H}} 3.90$ showed an HMBC correlation to $\mathrm{C}-4^{\prime \prime}\left(\delta_{\mathrm{C}} 155.5\right)$, which also correlated with the doublet of doublets $\mathrm{H}-2$ " and the meta-coupled doublet $\mathrm{H}-6^{\prime \prime}\left(\delta_{\mathrm{H}} 7.81\right.$ and 8.11 , respectively). It also showed a NOE correlation (ROESY experiment) to the ortho-coupled doublet H-3" $\left(\delta_{\mathrm{H}} 7.20\right)$ only, thus the methoxy group is located on the 1,2,4-trisubstituted aromatic ring. The structure was confirmed as 4 by HMBC correlations between $\mathrm{H}-6\left(\delta_{\mathrm{H}} 6.37\right)$ and both $\mathrm{C}-2$ " and C-6" $\left(\delta_{\mathrm{C}} 134.0\right.$ and 131.3). The single bromination of the benzylidene unit is consistent with all other congeners isolated as mixtures of $E / Z$ geometric isomers. This substitution pattern represents a new structure of the class and was therefore named rubrolide $U$. 


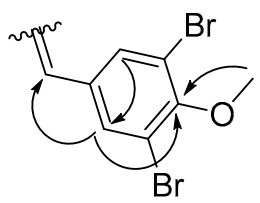

Substructure I<smiles>Cc1cc(Br)c2c(O)c1CCC2</smiles>

Substructure II

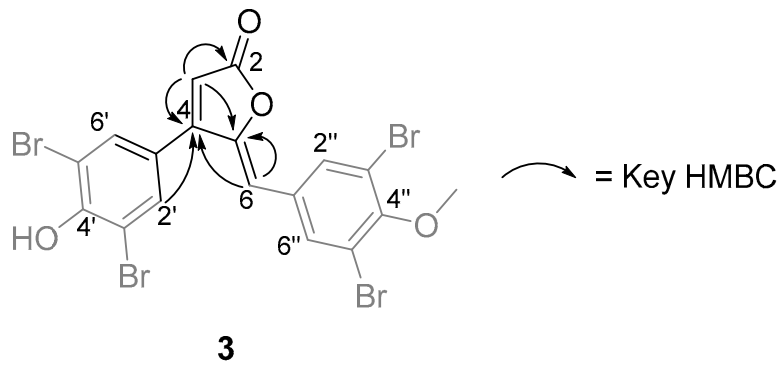

Figure 3. Key HMBC correlations completing the structure of 3.

Table 1. ${ }^{13} \mathrm{C}$ NMR $(150 \mathrm{MHz})$ data of compounds 3 and 4 (E- and Z-) in DMSO-d 6 ( $\delta$ in ppm).

\begin{tabular}{cccc}
\hline Carbon & 3 & $Z-4$ & $E-4$ \\
\hline 2 & $168.5, \mathrm{C}$ & $168.6, \mathrm{C}$ & $168.1, \mathrm{C}$ \\
3 & $105.7, \mathrm{CH}$ & $105.0, \mathrm{CH}$ & $110.3, \mathrm{CH}$ \\
4 & $156.7, \mathrm{C}$ & $156.8, \mathrm{C}$ & $154.7, \mathrm{C}$ \\
5 & $148.8, \mathrm{C}$ & $146.7, \mathrm{C}$ & $147.6, \mathrm{C}$ \\
6 & $108.2, \mathrm{CH}$ & $110.0, \mathrm{CH}$ & $113.8, \mathrm{CH}$ \\
$1^{\prime}$ & $129.9, \mathrm{C}$ & $131.6, \mathrm{C}$ & nd \\
$2^{\prime} / 6^{\prime}$ & $131.9, \mathrm{CH}$ & $131.5, \mathrm{CH}$ & $132.0, \mathrm{CH}$ \\
$3^{\prime} / 5^{\prime}$ & $115.8, \mathrm{C}$ & $115.4, \mathrm{C}$ & $114.3, \mathrm{C}$ \\
$4^{\prime}$ & $164.9, \mathrm{C}$ & $164.6, \mathrm{C}$ & $164.0, \mathrm{C}$ \\
$1^{\prime \prime}$ & $133.0, \mathrm{C}$ & $127.4, \mathrm{C}$ & $126.5, \mathrm{C}$ \\
$2^{\prime \prime}$ & $134.2, \mathrm{CH}$ & $131.1, \mathrm{CH}$ & $130.7, \mathrm{CH}$ \\
$3^{\prime \prime}$ & $117.7, \mathrm{C}$ & $112.6, \mathrm{CH}$ & $111.9, \mathrm{CH}$ \\
$4^{\prime \prime}$ & $153.1, \mathrm{C}$ & $155.3, \mathrm{C}$ & $155.4, \mathrm{C}$ \\
$5^{\prime \prime}$ & $117.7, \mathrm{C}$ & $110.7, \mathrm{C}$ & $110.3, \mathrm{C}$ \\
$6^{\prime \prime}$ & $134.2, \mathrm{CH}$ & $134.1, \mathrm{CH}$ & $134.1, \mathrm{CH}$ \\
$\mathrm{CH}_{3} \mathrm{O}-4{ }^{\prime \prime}$ & $60.6, \mathrm{CH}$ & $56.4, \mathrm{CH}$ & $56.2, \mathrm{CH}$ \\
\hline
\end{tabular}

Table 2. ${ }^{1} \mathrm{H}$ NMR (600 MHz) data of compounds 3 and 4 (E- and Z-) in DMSO- $\mathrm{d}_{6}(\delta$ in ppm, mult., $J$ in $\mathrm{Hz}$ ).

\begin{tabular}{cccc}
\hline Proton & 3 & $\mathrm{Z}-4$ & $E-4$ \\
\hline 3 & $6.21, \mathrm{~s}$ & $6.13, \mathrm{~s}$ & $6.18, \mathrm{~s}$ \\
6 & $6.44, \mathrm{~s}$ & $6.37, \mathrm{~s}$ & $6.88, \mathrm{~s}$ \\
$2^{\prime} / 6^{\prime}$ & $7.59, \mathrm{~s}$ & $7.56, \mathrm{~s}$ & $7.04, \mathrm{~s}$ \\
$2^{\prime \prime}$ & $8.15, \mathrm{~s}$ & $7.81, \mathrm{dd}(8.7,2.2)$ & $7.05, \mathrm{dd}(8.7,2.2)$ \\
$3^{\prime \prime}$ & & $7.19, \mathrm{~d}(8.7)$ & $6.87, \mathrm{~d}(8.7)$ \\
$6^{\prime \prime}$ & $8.15, \mathrm{~s}$ & $8.11, \mathrm{~d}(2.2)$ & $7.40, \mathrm{~d}(2.2)$ \\
$\mathrm{CH}_{3} \mathrm{O}-4^{\prime \prime}$ & $3.83, \mathrm{~s}$ & $3.90, \mathrm{~s}$ & $3.79, \mathrm{~s}$ \\
\hline
\end{tabular}

The remaining peaks in the ${ }^{1} \mathrm{H}$ NMR spectrum were assigned to the minor rubrolide $\mathrm{U}$ isomer $(E-4)$, based on relative peak intensity of the resonances in the two separate HPLC fractions, one enriched in E-4 and the other Z-4, in conjunction with chemical shift values and NOE (ROESY) (Figure 4) data. For $E-\mathbf{4}$, the two aromatic rings are closer in space, which results in increased shielding of the aromatic 
signals compared to Z-4, where they point away from each other. (Figure 3) In both cases, H-3 showed NOE correlations to H-2'/6', however for the $\mathrm{Z}$ isomer $\mathrm{H}-6$ correlated to $\mathrm{H}-2^{\prime} / 6^{\prime}, \mathrm{H}-2^{\prime \prime}$ and $\mathrm{H}-6^{\prime \prime}$, whereas it only correlated to $\mathrm{H}-2^{\prime \prime}$ and H-6" for the $E$ isomer. A correlation between $\mathrm{H}-2^{\prime} / 6^{\prime}$ and H-2" was also observed for the $E$ isomer but absent for $Z$, consistent with the two aromatic rings in a closer proximity and placing the sterically demanding $\mathrm{Br}$ atom away from the molecular core.

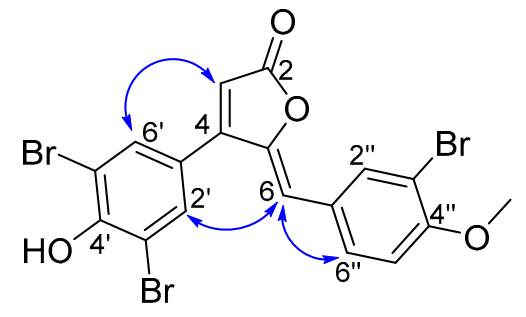

Z-4

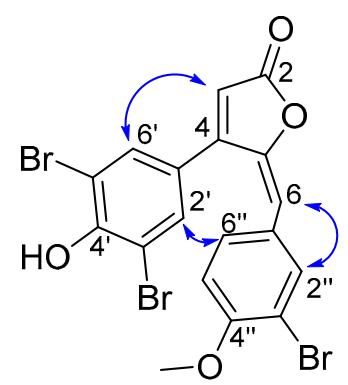

$E-4$

Figure 4. Key ROESY correlations for E- and Z-4.

Although the two HPLC samples were enriched for either E- or Z-4, over time, the proportion of the peaks corresponding to $Z-4$ increased, suggesting isomerization to this compound. The $Z$ isomer is favored, due to the reduction in steric repulsion between the two aromatic rings that are set co-planar to each other by the extended conjugation across the molecule. When the rubrolides are biosynthesized (vide infra), it is hypothesized that a final deprotonation forms $\Delta_{5,6}$, where both isomers could be formed if the conformation of the benzylidene ring allows it (Scheme 1). The electron density of the aromatic benzylidene group will help stabilize the positive charge formed in the conversion, particularly with the electron donating methoxy group at the para position. Of the four previous compounds reported to display this phenomenon, three also contained the methoxy group on the ring. In fact, the demethylated congeners of rubrolide $\mathrm{Q}$ and cadiolide $\mathrm{F}$ were not reported to be isolated as $E$ isomers, therefore, it is likely a combination of both factors contributing to carbocation stability. No conversion from the $Z$ to the $E$ isomer has been observed.

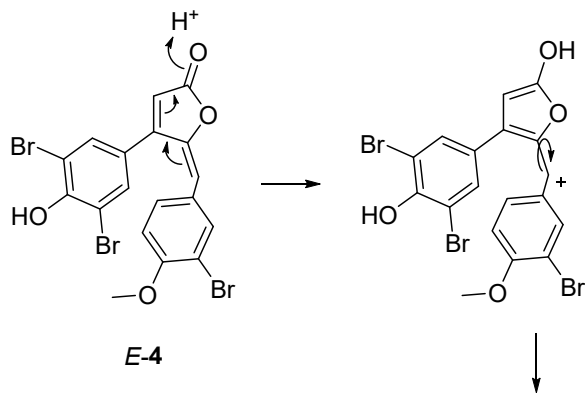<smiles>[Z4][X]</smiles><smiles>COc1ccc(CPc2coc(-c3cc(Br)c(O)c(Br)c3)c2)cc1Br</smiles>

Scheme 1. Isomerization from $E-$ to $Z-4$.

Although there are no reports formally investigating the biosynthesis of the marine derived polyaromatic butenolides, a related butenolide isolated from the fermentation broth of Aspergillus terreus 
var. africanus IFO 8835, was shown, through isotope incorporation studies, to be biosynthesized from the condensation of two molecules of tyrosine, and subsequent halogenation/methylation via an $\alpha$-keto acid $[33,34]$. These biosynthetic studies led Miao and Andersen to propose a biogenesis for the rubrolides (Scheme 2) [35]. Unlike the tunicate amino acid-derived alkaloids, the rubrolides do not contain the amino nitrogen, therefore the first step is the formation of the $\alpha$-keto acid 6 via transamination of 5. Through an Aldol-type condensation, two molecules form a reactive intermediate that then undergoes oxidative decarboxylation and reduction-dehydration to form the previously reported rubrolides $\mathrm{G}$ and $\mathrm{H}$ (7 and 8), after halogenation [22]. To form the remaining rubrolides, and by extension 3 and 4, this reactive intermediate would then undergo another dehydration, halogenation and methylation. The presence of interconverting $E$ and $Z$ isomers with the same halogenation patterns suggest that halogenation occurs before the dehydration reaction.
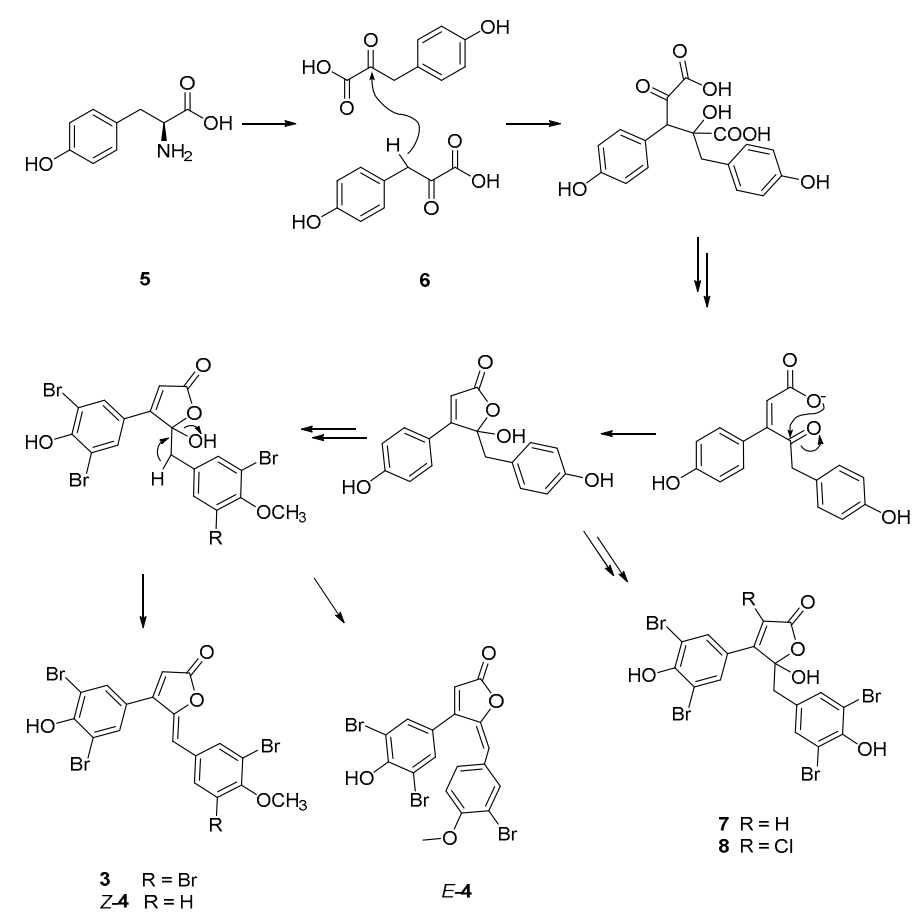

Scheme 2. Proposed biogenesis of the rubrolides. Adapted from Miao and Andersen [35].

All of compounds 1-4 showed strong inhibitory activity against $B$. subtilis, while no activity was detected against Escherichia coli at $128 \mu \mathrm{g} \mathrm{mL}^{-1}$ (Table 3). Many previously reported rubrolides have shown antimicrobial and cytotoxic activity against a range of targets, where a general trend has been observed that phenol methylation reduces activity in both synthetic [36] and a naturally isolated [23] analogues. However, compound 3 showed roughly ten-fold stronger activity than 1. All direct comparative studies that observed this decrease in antibacterial activity used other bacterial species such as MRSA, and Staphylococcus epidermidis [23], therefore, this may be a strain specific effect for the new rubrolides upon $B$. subtilis.

Table 3. Minimum inhibitory concentration (MIC) values for compounds 1-4 against B. subtilis. Tetracycline was used as a positive control.

\begin{tabular}{ccc}
\hline Compound & MIC $\left(\mu \mathrm{g} \mathrm{mL}^{-\mathbf{1}}\right)$ & $\mathrm{MIC}(\mu \mathrm{M})$ \\
\hline 1 & 2 & 3.36 \\
2 & 0.5 & 0.79 \\
3 & $\leq 0.25$ & $\leq 0.41$ \\
4 & 0.5 & 0.94 \\
Tetracycline & 2 & 4.5 \\
\hline
\end{tabular}




\section{Materials and Methods}

\subsection{General Procedures}

UV/Vis spectra were extracted from HPLC chromatograms. A $600 \mathrm{MHz}$ Varian Direct Drive spectrometer (Varian, Palo Alto, CA, USA) equipped with a $5 \mathrm{~mm}$ PFG dual broadband probe or a JEOL JNM-ECZ600R (JEOL, Tokyo, Japan) with a nitrogen cooled $5 \mathrm{~mm}$ SuperCOOL cryogenic probe were used to record the NMR spectra of all compounds $\left(600 \mathrm{MHz}\right.$ for ${ }^{1} \mathrm{H}$ nuclei and $150 \mathrm{MHz}$ for ${ }^{13} \mathrm{C}$ nuclei). The residual solvent peak was used as an internal reference for ${ }^{1} \mathrm{H}\left(\delta_{\mathrm{H}} 2.50, \mathrm{DMSO}-\mathrm{d}_{6}\right)$ and ${ }^{13} \mathrm{C}\left(\delta_{\mathrm{C}} 39.52\right.$, DMSO- $\left.\mathrm{d}_{6}\right)$ chemical shifts [37]. Samples were quantified by ${ }^{1} \mathrm{H}$ NMR spectroscopy using the residual DMSO- $\mathrm{d}_{5}$ peak, calibrated and acquired according to the parameters described by Pierens and co-workers [38]. Standard pulse sequences supplied by Varian and JEOL were used for NMR analyses. High-resolution (ESI) mass spectrometric data were obtained with an Agilent 6530 Accurate Mass Q-TOF LC-MS (Agilent, Santa Clara, CA, USA) equipped with a 1260 Infinity binary pump.

Reversed-phase column chromatography was achieved using Supelco Diaion HP-20 ${ }^{\circledR}$ (PSDVB) (Sigma-Aldrich, Bellefonte, PA, USA) chromatographic resin. HPLC purifications were carried out using a Rainin Dynamax SD-200 solvent delivery system with $25 \mathrm{~mL}$ pump heads with a Varian Prostar 335 diode array detector. Octadecyl-derivatized silica $\left(\mathrm{C}_{18}, 5 \mu \mathrm{m}, 100 \AA\right.$ A) HPLC columns (Phenomenex, Torrance, CA, USA) were either analytical $(4.6 \mathrm{~mm} \times 250 \mathrm{~mm}, 1 \mathrm{~mL} / \mathrm{min})$ or semi-preparative $(10 \mathrm{~mm} \times 250 \mathrm{~mm}, 4 \mathrm{~mL} / \mathrm{min})$. All solvents used were of HPLC grade and $\mathrm{H}_{2} \mathrm{O}$ was glass distilled. Solvent mixtures are reported as percent volume/volume. All reagents were of commercial quality, obtained from either Sigma Aldrich or AK Scientific and were used without prior purification.

\subsection{Collection of Synoicum kuranui}

The tunicate Synoicum kuranui was hand collected using SCUBA from Great Barrier Island, NZ in 1999, as part of the NIWA collection (catalogue number NIWA 101234 and MNP0303). The tunicate was identified by MJP. Frozen tunicate was stored at $-18^{\circ} \mathrm{C}$, until required.

\subsection{Extraction and Isolation}

The tunicate (24 g wet weight) was extracted in $\mathrm{MeOH}(100 \mathrm{~mL})$ twice overnight. The second extract, followed by the first, were passed through a HP-20 ${ }^{\circledR}$ column $(20 \mathrm{~mL})$, pre-equilibrated in $\mathrm{H}_{2} \mathrm{O}$ and combined following elution. The eluent was then diluted with an equal volume of $\mathrm{H}_{2} \mathrm{O}$ and passed back through the column twice, followed by a $60 \mathrm{~mL} \mathrm{H}_{2} \mathrm{O}$ wash. The column was then eluted with $60 \mathrm{~mL}$ portions of (1) $30 \% \mathrm{Me}_{2} \mathrm{CO} / \mathrm{H}_{2} \mathrm{O}$, (2) $75 \% \mathrm{Me}_{2} \mathrm{CO} / \mathrm{H}_{2} \mathrm{O}$, and (3) $\mathrm{Me}_{2} \mathrm{CO}$ (fractions A1-A3, respectively). Fractions $\mathrm{A} 2$ and $\mathrm{A} 3$ were then purified on a semi-preparative $\mathrm{C}_{18} \mathrm{HPLC}$ column, using isocratic $90 \% \mathrm{MeOH} / \mathrm{H}_{2} \mathrm{O}(0.2 \%$ formic acid $)$, generating fractions $\mathrm{B} 1-\mathrm{B} 4$ and $\mathrm{C} 1-\mathrm{C} 7$ respectively. Fractions B3 and C7 afforded solely rubrolide $1\left(0.65 \mathrm{mg}, \mathrm{t}_{\mathrm{R}}=6.3 \mathrm{~min}\right)$ and $3\left(0.15 \mathrm{mg}, \mathrm{t}_{\mathrm{R}}=9.9 \mathrm{~min}\right)$, respectively. Fractions B4 and C5 were further purified on an analytical $\mathrm{C}_{18} \mathrm{HPLC}$ column using $80 \%$ $\mathrm{MeOH} / \mathrm{H}_{2} \mathrm{O}(0.2 \% \mathrm{FA})$ to afford rubrolide $E-4\left(0.05 \mathrm{mg}, \mathrm{t}_{\mathrm{R}}=6.3 \mathrm{~min}\right), \mathrm{Z}-4\left(0.26 \mathrm{mg}, \mathrm{t}_{\mathrm{R}}=9.9 \mathrm{~min}\right)$ and 2 $\left(0.35 \mathrm{mg}, \mathrm{t}_{\mathrm{R}}=13.1 \mathrm{~min}\right)$. The two separate 4 samples were combined for NMR analysis.

Rubrolide A (1) yellow film; HRESIMS m/z 590.7075 [M - H] $]^{-}$(calcd. for $\mathrm{C}_{17} \mathrm{H}_{7} \mathrm{Br}_{4} \mathrm{O}_{4}, 590.7083$ ); all NMR data matches those previously reported [22].

Rubrolide B (2) yellow film; HRESIMS m/z 624.6694 [M - H] $]^{-}$(calcd. for $\mathrm{C}_{17} \mathrm{H}_{6} \mathrm{Br}_{4} \mathrm{ClO}_{4}, 624.6694$ ); all NMR data matches those previously reported [22].

Rubrolide $T$ (3) yellow film; UV (MeOH/H $\left.\mathrm{H}_{2} \mathrm{O}\right) \lambda_{\max } 230,250,257$ (sh), $340 \mathrm{~nm} ;{ }^{13} \mathrm{C}$ and ${ }^{1} \mathrm{H}$ NMR data, Tables 1 and 2 respectively; HRESIMS $m / z$ 604.7254 [M - H] $]^{-}$(calcd. for $\mathrm{C}_{18} \mathrm{H}_{9} \mathrm{Br}_{4} \mathrm{O}_{4}, 604.7240$ ); HRESIMS/MS (50 eV) m/z (\% relative intensity) 589.6992 (5.4), 545.7086 (3.1), 510.7802 (20.8), 482.7853 
E/Z-Rubrolide U (4) yellow film; UV (MeOH/ $\left.\mathrm{H}_{2} \mathrm{O}\right) \lambda_{\max } 232,254,361 \mathrm{~nm} ;{ }^{13} \mathrm{C}$ and ${ }^{1} \mathrm{H}$ NMR data, Tables 1 and 2 respectively; HRESIMS $m / z 526.8143[\mathrm{M}-\mathrm{H}]^{-}$(calcd. for $\mathrm{C}_{18} \mathrm{H}_{10} \mathrm{Br}_{3} \mathrm{O}_{4}, 526.8135$ ); HRESIMS/MS (50 eV) m/z (\% relative intensity) 511.7898 (3.4), 483.7952 (3.0), 467.8005 (3.3), 432.8721 (12.5), 404.8767 (5.0), 375.8743 (20.0), 295.9485 (22.5), 272.8561 (50), 78.9194 (100).

\section{4. $L C-M S^{2}$ Analysis and Molecular Networking}

The HP-20 ${ }^{\circledR}$ fractions (A1 and $\mathrm{A} 3,1 \mathrm{mg} / \mathrm{mL}$ in $\mathrm{MeOH}$ ) were analyzed using the aforementioned mass spectrometer, operating in (-)-polarity at a mass range of $m / z 50-1500$. Instrumental parameters for data acquisition were set as follows: capillary voltage of $3500 \mathrm{~V}$, nebulizer gas $\left(\mathrm{N}_{2}\right)$ pressure of $30 \mathrm{psig}$, ion source temperature of $275^{\circ} \mathrm{C}$, sheath gas temperature of $300{ }^{\circ} \mathrm{C}$ and flow of $7 \mathrm{~L} / \mathrm{min}$, and the acquisition rate was three spectra/s. The ion isolation width was set wide at $7 \mathrm{amu}$. Minutes 0-0.5 were sent to waste and minutes $0.5-25$ recorded with untargeted ion fragmentation (auto-MS ${ }^{2}$ ), where the collision induced dissociation (CID) energies were dependent on the precursor mass determined by the pre-set equations CID $=2.62 x+14.75$ (low energy) and CID $=3.93 x+22.13$ (high energy). The five most intense ions per MS scan were subjected to CID and were actively excluded after three spectra for $0.3 \mathrm{~min}$.

The samples were injected (injection volume: $10 \mu \mathrm{L}$ ) into the system equipped with an Eclipse Plus reversed-phase $\mathrm{C}_{18}$ column $\left(30 \mathrm{~mm} \times 2.1 \mathrm{~mm}, 3.5 \mu \mathrm{m}\right.$; Agilent Technologies) at $35^{\circ} \mathrm{C}$. Compound separation was achieved using mobile phase A $99.9 \% \mathrm{H}_{2} \mathrm{O} / 0.1 \% \mathrm{NH}_{4} \mathrm{HCO}_{2}$ and $\mathrm{B} 99.9 \% \mathrm{ACN} / 0.1 \%$ $\mathrm{FA}$, at $0.4 \mathrm{~mL} / \mathrm{min}$ with the following gradient method: $0-1 \mathrm{~min} 2.5 \% \mathrm{~B}, 1-20 \mathrm{~min} 2.5 \%-100 \% \mathrm{~B}$, 20-25 $\mathrm{min} 100 \% \mathrm{~B}$ and a column re-equilibration period for $3 \mathrm{~min}$.

The LC-MS ${ }^{2}$ data was converted to MGF files using Agilent's Masshunter (qualitative analysis software, B.04.00) and uploaded to GNPS, which was used to create a molecular network [1]. $\mathrm{MS}^{2}$ fragment ions within \pm 17 Da of the parent $\mathrm{m} / \mathrm{z}$ were removed. $\mathrm{MS}^{2}$ spectra were then window filtered, selecting the six largest peaks within a window of $50 \mathrm{~m} / \mathrm{z}$ before clustering with MS-Cluster using tolerances of 2.0 Da for the parent and 0.5 Da for $\mathrm{MS}^{2}$ ions, to generate consensus spectra, although any consensus spectrum containing only 0-2 spectra was removed. Filtering of network edges to giving $>$ four matched peaks, with cosine score $>0.6$, was applied to form the ultimate network. Only those edges connecting two nodes that appeared within its partner top 10 most similar nodes were retained within the network. Online spectral databases stored within GNPS were used for node dereplication/annotation; all library fragmentation data were filtered identically as experimental data. Matches between library and the experimental data were kept only if a cosine score greater than 0.7 was obtained, with a minimum of six matching ions. The experimental data can be obtained from: https://gnps.ucsd.edu/ProteoSAFe/status.jsp?task=0faf2a77b21b457c9a047343e9b813e0\#. All MNs were viewed using Cytoscape 3.7.0. [39].

\subsection{Antibacterial Bioassay}

Minimum inhibitory concentration (MIC) studies were performed using an established protocol [40] to test isolated compounds against test strains of E. coli BL21 and B. subtilis 168. All tests were carried out in $\mathrm{MH}$ medium at $30^{\circ} \mathrm{C}$, with $16 \mathrm{~h}$ growth time in biological triplicates ( $n=3$ independent experiments). A positive control of tetracycline and negative control DMSO were included in the analysis. All compounds were assayed from $128 \mu \mathrm{g} / \mathrm{mL}$ in two-fold serial dilution steps across 10 dilution stages to the lowest concentration tested $0.25 \mu \mathrm{g} / \mathrm{mL}$. Sterility (media only) and growth (cells only) controls were included in each plate assayed.

\section{Conclusions}

GNPS is a powerful tool for the detection and discovery of new variations of previously reported metabolites within a complex chemical extract. Although the rubrolides have been thoroughly 
investigated, the MN revealed two previously unreported precursor ions, which upon a targeted isolation, led to the isolation of new rubrolides T (3) and E/Z-U (4) Based on the difference in $\mathrm{m} / \mathrm{z}$ of the neighboring precursor ions, the molecular formula was predicted, which streamlined the ensuing NMR spectroscopy-based structure elucidation. Both $\mathbf{3}$ and $\mathbf{4}$ showed strong growth inhibition against B. subtilis, but no activity against E. coli. This finding is significant in that it differs from a lack of biological activity for methylated rubrolides against Gram positive bacteria previously reported and is worthy of future investigation. This work reflects how MN can be used to probe complex extracts for the presence of new bioactive, albeit minor, compounds.

Supplementary Materials: The following are available online at http://www.mdpi.com/1660-3397/18/7/337/s1. Figure S1: Full molecular network of Pacific tunicates, Figure S2: Underwater photos of Synoicum kuranui, Scheme S1: Isolation procedure, Figure S3: ${ }^{1} \mathrm{H}$ NMR spectrum screen of the screening fraction, Table S1: NMR data for Rubrolide T (3), Figure S4: ${ }^{1} \mathrm{H}$ NMR Spectrum of 3, Figure S5: ${ }^{13} \mathrm{C}$ NMR Spectrum of 3, Figure S6: HSQC NMR Spectrum of 3, Figure S7: HMBC NMR Spectrum of 3, Figure S8: (-)-HRESIMS spectra of 3, Figure S9: (-)-HRESIMS/MS spectrum of 3, Figure S10: UV/Vis spectrum of 3, Table S2: NMR data for Z-Rubrolide U (Z-4), Table S3: NMR data for E-Rubrolide U (E-4), Figure S11 - 1H NMR Spectrum of 4, Figure S12: ${ }^{13} \mathrm{C}$ NMR Spectrum of 4, Figure S13: COSY NMR Spectrum of 4, Figure S14: ROESY NMR Spectrum of 4, Figure S15: HSQC NMR Spectrum of 4, Figure S16: HMBC NMR Spectrum of 4, Figure S17: (-)-HRESIMS spectra of 4, Figure S18: (-)-HRESIMS/MS spectrum of 4, Figure S19: UV/Vis spectrum of 4.

Author Contributions: All the authors contributed to the conceptualisation of the manuscript; isolation and structural elucidation, J.B. and R.A.K.; biological evaluation, L.J.S. and J.G.O.; species identification, M.J.P.; writing - original draft preparation, J.B., and writing - review and editing, R.A.K. All authors have read and agreed to the published version of the manuscript.

Funding: This research received no external funding. J.B. is thankful for the VUW Doctoral Scholarship and Curtis Gordon Research Scholarship.

Acknowledgments: Jan Vorster (VUW) is thanked for NMR and MS assistance. NIWA is thanked for access to the marine sample.

Conflicts of Interest: The authors declare no conflict of interest.

\section{References}

1. Wang, M.; Carver, J.J.; Phelan, V.V.; Sanchez, L.M.; Garg, N.; Peng, Y.; Nguyen, D.D.; Watrous, J.; Kapono, C.A.; Luzzatto-Knaan, T.; et al. Sharing and community curation of mass spectrometry data with Global Natural Products Social Molecular Networking. Nat. Biotech. 2016, 34, 828-837. [CrossRef] [PubMed]

2. Fox Ramos, A.E.; Evanno, L.; Poupon, E.; Champy, P.; Beniddir, M.A. Natural products targeting strategies involving molecular networking: different manners, one goal. Nat. Prod. Rep. 2019, 36, 960-980. [CrossRef] [PubMed]

3. Li, Y.; Yu, H.-B.; Zhang, Y.; Leao, T.; Glukhov, E.; Pierce, M.L.; Zhang, C.; Kim, H.; Mao, H.H.; Fang, F.; et al. Pagoamide A, a Cyclic Depsipeptide Isolated from a Cultured Marine Chlorophyte, Derbesia sp., Using MS/MS-Based Molecular Networking. J. Nat. Prod. 2020, 83, 617-625. [CrossRef] [PubMed]

4. Bonneau, N.; Chen, G.; Lachkar, D.; Boufridi, A.; Gallard, J.F.; Retailleau, P.; Petek, S.; Debitus, C.; Evanno, L.; Beniddir, M.A.; et al. An Unprecedented Blue Chromophore Found in Nature using a "Chemistry First" and Molecular Networking Approach: Discovery of Dactylocyanines A-H. Chem. Eur. J. 2017, 23, 14454-14461. [CrossRef] [PubMed]

5. Zou, Y.; Wang, X.; Sims, J.; Wang, B.; Pandey, P.; Welsh, C.L.; Stone, R.P.; Avery, M.A.; Doerksen, R.J.; Ferreira, D.; et al. Computationally Assisted Discovery and Assignment of a Highly Strained and PANC-1 Selective Alkaloid from Alaska's Deep Ocean. J. Am. Chem. Soc. 2019, 141, 4338-4344. [CrossRef] [PubMed]

6. Khushi, S.; Salim, A.A.; Elbanna, A.H.; Nahar, L.; Bernhardt, P.V.; Capon, R.J. Dysidealactams and Dysidealactones: Sesquiterpene Glycinyl-Lactams, Imides, and Lactones from a Dysidea sp. Marine Sponge Collected in Southern Australia. J. Nat. Prod. 2020, 83, 1577-1584. [CrossRef] [PubMed]

7. Antunes, E.M.; Copp, B.R.; Davies-Coleman, M.T.; Samaai, T. Pyrroloiminoquinone and related metabolites from marine sponges. Nat. Prod. Rep. 2005, 22, 62-72. [CrossRef]

8. Kalinski, J.C.J.; Waterworth, S.C.; Siwe Noundou, X.; Jiwaji, M.; Parker-Nance, S.; Krause, R.W.M.; McPhail, K.L.; Dorrington, R.A. Molecular Networking Reveals Two Distinct Chemotypes in Pyrroloiminoquinone-Producing Tsitsikamma favus Sponges. Mar. Drugs 2019, 17, 60. [CrossRef] 
9. Li, F.; Janussen, D.; Peifer, C.; Pérez-Victoria, I.; Tasdemir, D. Targeted Isolation of Tsitsikammamines from the Antarctic Deep-Sea Sponge Latrunculia biformis by Molecular Networking and Anticancer Activity. Mar. Drugs 2018, 16, 268. [CrossRef]

10. Bracegirdle, J.; Gordon, D.P.; Harvey, J.E.; Keyzers, R.A. Kinase-Inhibitory Nucleoside Derivatives from the Pacific Bryozoan Nelliella nelliiformis. J. Nat. Prod. 2020, 83, 547-551. [CrossRef]

11. Taufa, T.; Singh, A.J.; Harland, C.R.; Patel, V.; Jones, B.; Halafihi, T.; Miller, J.H.; Keyzers, R.A.; Northcote, P.T. Zampanolides B-E from the Marine Sponge Cacospongia mycofijiensis: Potent Cytotoxic Macrolides with Microtubule-Stabilizing Activity. J. Nat. Prod. 2018, 81, 2539-2544. [CrossRef] [PubMed]

12. Taufa, T.; Gordon, R.M.A.; Hashmi, M.A.; Hira, K.; Miller, J.H.; Lein, M.; Fromont, J.; Northcote, P.T.; Keyzers, R.A. Pyrroloquinoline derivatives from a Tongan specimen of the marine sponge Strongylodesma tongaensis. Tetrahedron Lett. 2019, 60, 1825-1829. [CrossRef]

13. Woolner, V.H.; Gordon, R.M.A.; Miller, J.H.; Lein, M.; Northcote, P.T.; Keyzers, R.A. Halogenated Meroditerpenoids from a South Pacific Collection of the Red Alga Callophycus serratus. J. Nat. Prod. 2018, 81, 2446-2454. [CrossRef] [PubMed]

14. Bracegirdle, J.; Robertson, L.P.; Hume, P.A.; Page, M.J.; Sharrock, A.V.; Ackerley, D.F.; Carroll, A.R.; Keyzers, R.A. Lamellarin Sulfates from the Pacific Tunicate Didemnum ternerratum. J. Nat. Prod. 2019, 82, 2000-2008. [CrossRef]

15. Carroll, A.R.; Copp, B.R.; Davis, R.A.; Keyzers, R.A.; Prinsep, M.R. Marine natural products. Nat. Prod. Rep. 2020, 37, 175-223. [CrossRef]

16. World Register of Marine Species 2020. Available online: http://www.marinespecies.org/ (accessed on 26 June 2020).

17. Diyabalanage, T.; Amsler, C.D.; McClintock, J.B.; Baker, B.J. Palmerolide A, a Cytotoxic Macrolide from the Antarctic Tunicate Synoicum adareanum. J. Am. Chem. Soc. 2006, 128, 5630-5631. [CrossRef]

18. Tadesse, M.; Strøm, M.B.; Svenson, J.; Jaspars, M.; Milne, B.F.; Tørfoss, V.; Andersen, J.H.; Stensvåg, K.; Haug, T. Synoxazolidinones A and B: Novel Bioactive Alkaloids from the Ascidian Synoicum pulmonaria. Org. Lett. 2010, 12, 4752-4755. [CrossRef]

19. Tadesse, M.; Svenson, J.; Jaspars, M.; Strøm, M.B.; Abdelrahman, M.H.; Andersen, J.H.; Hansen, E.; Kristiansen, P.E.; Stensvåg, K.; Haug, T. Synoxazolidinone C; a bicyclic member of the synoxazolidinone family with antibacterial and anticancer activities. Tetrahedron Lett. 2011, 52, 1804-1806. [CrossRef]

20. Tadesse, M.; Svenson, J.; Sepčić, K.; Trembleau, L.; Engqvist, M.; Andersen, J.H.; Jaspars, M.; Stensvåg, K.; Haug, T. Isolation and Synthesis of Pulmonarins A and B, Acetylcholinesterase Inhibitors from the Colonial Ascidian Synoicum pulmonaria. J. Nat. Prod. 2014, 77, 364-369. [CrossRef]

21. Shen, G.Q.; Baker, B.J. Biosynthetic studies of eudistomin H in the tunicate Eudistoma olivaceum. Tetrahedron Lett. 1994, 35, 4923-4926. [CrossRef]

22. Miao, S.; Andersen, R.J. Rubrolides A-H, metabolites of the colonial tunicate Ritterella rubra. J. Org. Chem. 1991, 56, 6275-6280. [CrossRef]

23. Sikorska, J.; Parker-Nance, S.; Davies-Coleman, M.T.; Vining, O.B.; Sikora, A.E.; McPhail, K.L. Antimicrobial Rubrolides from a South African Species of Synoicum Tunicate. J. Nat. Prod. 2012, 75, 1824-1827. [CrossRef] [PubMed]

24. Ortega, M.J.; Zubía, E.; Ocaña, J.M.; Naranjo, S.; Salvá, J. New Rubrolides from the Ascidian Synoicum blochmanni. Tetrahedron 2000, 56, 3963-3967. [CrossRef]

25. Pearce, A.N.; Chia, E.W.; Berridge, M.V.; Maas, E.W.; Page, M.J.; Webb, V.L.; Harper, J.L.; Copp, B.R. E/Z-Rubrolide $\mathrm{O}$, an Anti-inflammatory Halogenated Furanone from the New Zealand Ascidian Synoicum. sp. J. Nat. Prod. 2007, 70, 111-113. [CrossRef]

26. Smitha, D.; Kumar, M.M.K.; Ramana, H.; Rao, D.V. Rubrolide R: A new furanone metabolite from the ascidian Synoicum of the Indian Ocean. Nat. Prod. Res. 2014, 28, 12-17. [CrossRef] [PubMed]

27. Wang, W.; Kim, H.; Nam, S.J.; Rho, B.J.; Kang, H. Antibacterial Butenolides from the Korean Tunicate Pseudodistoma antinboja. J. Nat. Prod. 2012, 75, 2049-2054. [CrossRef]

28. Zhu, T.; Chen, Z.; Liu, P.; Wang, Y.; Xin, Z.; Zhu, W. New rubrolides from the marine-derived fungus Aspergillus terreus OUCMDZ-1925. J. Antibiot. 2013, 67, 315. [CrossRef] [PubMed]

29. Brewin, B.J. Ascidians of New Zealand. Part 5: Ascidians from the East Coast of Great Barrier Island. Trans. R. Soc. N.Z. 1950, 78, 354-362. 
30. Page, M.J.; Kelly, M. Awesome Ascidians-A Guide to the Sea Squirts of New Zealand 2016. Available online: https://niwa.co.nz/coasts-and-oceans/marine-identification-guides-and-fact-sheets/seasquirt-idguide (accessed on 26 June 2020).

31. Marinlit 2019. Available online: http://pubs.rsc.org/marinlit/ (accessed on 26 June 2020).

32. Wang, W.; Kim, H.; Patil, R.S.; Giri, A.G.; Won, D.H.; Hahn, D.; Sung, Y.; Lee, J.; Choi, H.; Nam, S.J.; et al. Cadiolides J-M, antibacterial polyphenyl butenolides from the Korean tunicate Pseudodistoma antinboja. Bioorg. Med. Chem. Lett. 2017, 27, 574-577. [CrossRef]

33. Kiriyama, N.; Nitta, K.; Sakaguchi, Y.; Taguchi, Y.; Yamamoto, Y. Studies on the Metabolic Products of Aspergillus terreus. III. Metabolites of the Strain IFO 8835. (1). Chem. Pharm. Bull. 1977, 25, 2593-2601. [CrossRef]

34. Nitta, K.; Fujita, N.; Yoshimura, T.; Arai, K.; Yamamoto, Y. Metabolic Products of Aspergillus terreus. IX. Biosynthesis of Butyrolactone Derivatives isolated from Strains IFO 8835 and 4100. Chem. Pharm. Bull. 1983, 31, 1528-1533. [CrossRef]

35. Miao, S. Novel Secondary Metabolites from Selected Marine Invertebrates. Ph.D. Thesis, University of British Columbia, Vancouver, BC, Canada, 1985.

36. Bellina, F.; Anselmi, C.; Martina, F.; Rossi, R. Mucochloric Acid: A Useful Synthon for the Selective Synthesis of 4-Aryl-3-chloro-2(5H)-furanones, (Z)-4-Aryl-5-[1-(aryl)methylidene]-3-chloro-2(5H)-furanones and 3,4-Diaryl-2(5H)-furanones. Eur. J. Org. Chem. 2003, 2003, 2290-2302. [CrossRef]

37. Fulmer, G.R.; Miller, A.J.M.; Sherden, N.H.; Gottlieb, H.E.; Nudelman, A.; Stoltz, B.M.; Bercaw, J.E.; Goldberg, K.I. NMR Chemical Shifts of Trace Impurities: Common Laboratory Solvents, Organics, and Gases in Deuterated Solvents Relevant to the Organometallic Chemist. Organometallics 2010, 29, 2176-2179. [CrossRef]

38. Pierens, G.K.; Carroll, A.R.; Davis, R.A.; Palframan, M.E.; Quinn, R.J. Determination of Analyte Concentration Using the Residual Solvent Resonance in 1H NMR Spectroscopy. J. Nat. Prod. 2008, 71, 810-813. [CrossRef] [PubMed]

39. Shannon, P.; Markiel, A.; Ozier, O.; Baliga, N.S.; Wang, J.T.; Ramage, D.; Amin, N.; Schwikowski, B.; Ideker, T. Cytoscape: A software environment for integrated models of biomolecular interaction networks. Genome Res. 2003, 13, 2498-2504. [CrossRef]

40. Wiegand, I.; Hilpert, K.; Hancock, R.E.W. Agar and broth dilution methods to determine the minimal inhibitory concentration (MIC) of antimicrobial substances. Nat. Protoc. 2008, 3, 163-175. [CrossRef] 